\title{
The Effectiveness of Problem-based Learning in Terms of Learning Achievement, Problem-Solving, and Self- Confidence
}

\author{
Raoda Ismail ${ }^{1,2^{*}}$, Okky Riswandha Imawan ${ }^{1,2}$ \\ ${ }^{I}$ Educational Research and Evaluation Department, Universitas Negeri Yogyakarta, Indonesia \\ ${ }^{2}$ Mathematics Education Department, Universitas Cenderawasih, Indonesia \\ "Corresponding author.Email: raodaismail26@gmail.com, raodaismail.2021@student.uny.ac.id
}

\begin{abstract}
This study aimed to describe the effectiveness of Problem-Based Learning in terms of learning achievement, problemsolving, and student confidence in the Statistics course. The stages of the problem-based learning model are (1) finding the problem; (2) building a work structure; (3) defining the problem; (4) collecting various information; (5) formulating solutions; and (6) evaluation. This study is a quasi-experimental research. The subjects in this study were 34 students of the Mathematics Education Study Program at Cenderawasih University. The instruments used in this study consisted of learning achievement test instruments, problem-solving ability tests, self-confidence questionnaires, and learning implementation observation sheets. Descriptive analysis and statistical analysis are data analysis techniques used in this study. Statistical analysis using the z proportion test at a significant level of $95 \%$. The results showed that problem-based learning was effective in learning achievement, problem-solving skills, and selfconfidence.
\end{abstract}

Keywords: Learning achievement, Problem-based learning, Problem solving, Self-confidence

\section{INTRODUCTION}

Education is one of the primary capital essential to building quality human resources. In general, instruction is translated into a curriculum so that it is easy to implement to achieve education goals. It is necessary to profile the qualifications of graduates' abilities to achieve the national education goals. The profile is contained in the competency standards of graduates based on Law Number 20 of 2003 concerning the National Education System in Indonesia. Therefore, the curriculum plays a fundamental role in realizing educational goals.

Today, the curriculum that applies at universities in Indonesia is the Indonesian National Qualifications Framework-based curriculum. The competency standards of graduates based on the Indonesian national qualification framework are then translated into aspects of attitudes, knowledge, and skills. The competencies empower potential and assist students in improving their attitudes, knowledge, and skills [1].
Students in the Mathematics Education Study Program are future mathematics teachers. Therefore, as prospective mathematics teachers, mathematics education students must master mathematical concepts well, especially statistical concepts, to support a teacher's professionalism [2]. Professional teachers can assist students in achieving their learning goals [3]. The mastery of the teacher's material with learning achievement has a positive relationship [4]. Learning achievement shows understanding and skill of the material being studied as evidence of achieving learning objectives [5],[7]. It indicates that the importance of mastery of knowledge.

Prospective teachers are expected to master both knowledge competencies and skill competencies. One of the crucial skills in everyday life that must be mastered is problem-solving skills. Problem-solving is a practical skill that is quite common and can be learned because it involves various thought processes, including analysis, interpretation, reasoning, prediction, evaluation, and reflection. Problem-solving skills include four phases of 
skills, namely (a) understanding the problem (objectives, known and unknown information); (b) developing a plan or approach solution; (c) implementing the plan and confirming the correctness of its implementation; and (d) examining solutions, confirming the results and considering whether there are other possible alternatives [8], [10].

Prospective teachers are expected to master the aspects of knowledge and skills and master the elements of attitude. Student-teacher candidates must have good self-confidence so that their duties as teachers can run well in the future. Self-confidence is one of the reasons a person can complete his duties well in society [11]. Self-confidence is a person's belief in his abilities without being dependent on others, so he can be optimistic in acting and being responsible for the consequences of his actions [12]. Apart from that, with self-confidence, students can take appropriate and effective steps in various situations, even if they arise from themselves or others [13]. So that self-confidence affects one's learning achievement and affects daily interactions in the social environment of society.

In problem-based learning, a stimulus is given using contextual problems. Through problem-solving activities, it is hoped that students' learning skills, selfconfidence, and achievement in education can increase. Problem-based learning, which is identical to using nonroutine problems in learning activities, can develop problem-solving skills, materials, and self-regulation [14]. It can be formed through the process of each stage of learning, namely: (1) finding problems; (2) building a work structure; (3) defining the problem; (4) collecting various information; (5) formulating solutions; and (6) evaluate [11], [15-19].

Suppose a student has a good understanding of a concept. The student can relate the concept to other concepts, both in mathematics and outside of it, as an independent form of learning [20]. It can increase their knowledge as prospective teachers and their students' ability in the future. For example, a good mastery of statistical concepts will enable a student to relate the roles of descriptive statistics and inferential statistics to solving problems related to statistics. So, when there are problems in everyday life related to statistical concepts, a student can solve these problems more efficiently.

In addition to a good understanding of the teaching material, students must have good self-confidence as prospective mathematics teachers. Self-confidence is essential so that a person can carry out his duties well in society [11]. Confidence is needed by students when they become teachers and when they are in college. The importance of self-confidence in lectures is that students have independence in doing their tasks. Freedom will make students not dependent on others in doing their duty. With independence, students will be more confident in their ability to overcome a problem. With good self-confidence, students can carry out all the exercises to become good teachers, for example, carrying out learning practices at school or explaining their thoughts in class discussions.

Confidence is needed for a teacher to convey information correctly and adequately in front of students. In addition, good self-confidence will allow a teacher to produce creative ideas in managing learning activities and have a sense of optimism about the success of the actions he takes. High self-confidence from a teacher is expected to emit a positive aura through his words and efforts to increase student's motivation to learn the material, especially mathematics. If students have high motivation to learn the material and are accompanied by positive advice from the teacher, their confidence in learning the material will increase. It is expected to reduce the fear of students in learning mathematics, especially in working on complex mathematical problems.

Some of the explanations above illustrated the importance of self-confidence for prospective mathematics teacher students. Everyone's confidence level is different; some have low, medium, high, and very high self-confidence. In this study, the criteria for good self-confidence are high or very high. Not all students in the class have high or very high selfconfidence. Therefore, the student's self-confidence needs to be increased through the lecture process, which can increase self-confidence to achieve high or very high criteria.

Therefore, this study aims to describe the effectiveness of the problem-based learning model in terms of learning achievement, problem-solving skills, and self-confidence of prospective mathematics teacher students.

\section{METHOD}

This study is a quasi-experimental design. The population in this study were prospective mathematics teacher students at the Mathematics Education Study Program at Cenderawasih University. The sample in this study was Class B students, randomly selected from two classes, where the two classes had relatively the same level of knowledge. Figure 1 shows the research design used in this study [21].

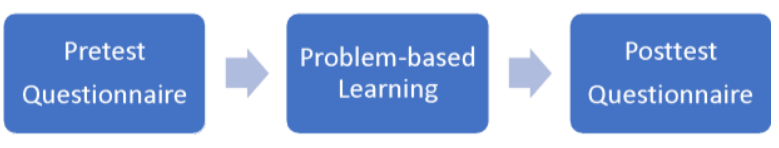

Figure 1. Research Design

The data in this study were collected using test and non-test techniques. The test is used to measure student achievement and problem-solving skills, while the nontest measures students' self-confidence. The instruments include learning achievement questions, problemsolving skills questions, student self-confidence 
questionnaires, and problem-based learning implementation observation sheets.

The expert's assessment shows that the content validity of the test instruments and questionnaires is feasible to use. In terms of construct validity, based on the confirmatory factor analysis results on the selfconfidence questionnaire, and obtained a KMO value of 0.58 . The result of factor analysis shows that there are five components in self-confidence. The results of the exploratory factor analysis follow the theoretical studies. The overall learning devices and instruments have met the validity criteria and are suitable for the learning process.

Furthermore, the instrument reliability estimation is carried out. The instrument is declared reliable if the minimum estimated reliability value obtained is 0.65 [22]. Based on the results of the reliability estimation, the three tools are reported reliable. Instrument reliability results are presented in Table 1.

Table 1. Estimation of research instruments reliability

\begin{tabular}{|l|l|}
\hline Instrument & Reliability \\
\hline Learning achievement & 0,774 \\
\hline Problem solving & 0,725 \\
\hline Self confidence & 0,660 \\
\hline
\end{tabular}

The analytical technique used is not only descriptive analysis but also statistical analysis. The data is described based on the average, maximum, and minimum scores. Statistical analysis using the proportion test. The data used in the statistical analysis is posttest data. The proportion test is used to analyze whether problem-based learning is effective in learning achievement, problem-solving skills, and selfconfidence. However, before carrying out statistical analysis, it is necessary to prove the assumptions first; the data comes from a normally distributed population. The data analysis technique used is normality test and hypothesis testing. Normality test using Chi-Square criteria c2 [23], with value criteria $d i 2<X 2(0,5)$ close to $50 \%$ of the data can be said to be normally distributed. The normality test is used to determine whether the data comes from a population that is normally distributed or not. Furthermore, hypothesis testing aims to assess the effectiveness of problembased learning in terms of learning achievement, problem-solving skills, and student self-confidence.

Problem-based learning model can be declared effective if the proportion of prospective teachers who have achieved a learning achievement score of 70 is more than $75 \%$. On the other hand, the proportion of students who have completed a problem-solving skill score in the minimum good category is more than $75 \%$. The ratio of students who have achieved a confidence score in the minimal category "well " is more than $75 \%$. Statistical testing was carried out at the significant level
$=5 \%$, and the test statistics were as in the following formula equation. $Z=\frac{\frac{x}{n-\pi_{0}}}{\sqrt{\frac{\pi_{0}-q_{0}}{n}}}$

where $\mathrm{x}$ is the number of teacher candidates who meet the specified criteria, $\square_{0}$ is the proportion of the hypothesized sample, $\mathrm{q}_{0}=1-\square_{0}$, and $\mathrm{n}$ is the number of students [24].

\section{RESULTS AND DISCUSSION}

\subsection{Results}

The mathematics learning achievement test was given to 34 students who were the research subjects. The results of the description analysis related to learning achievement are summarized in Table 2.

Table 2. Learning achievement test results

\begin{tabular}{|l|l|}
\hline Styles & Shortcuts \\
\hline Description & 95 \\
\hline The highest score & 50 \\
\hline Lowest Value & 23 \\
\hline Completed student & 5 \\
\hline Student not finished & $82,14 \%$ \\
\hline
\end{tabular}

Based on the data collected from the research results, the $\mathrm{Z}$ proportion test is carried out. Problem-based learning is declared effective if the proportion of student-teacher candidates who achieve a learning achievement score of 70 is more than $70 \%$. Based on the sample data obtained, $\mathrm{Z}=1.986$ and $\mathrm{Z} 0.05=1.645$ means $\mathrm{Z}>\mathrm{Za}$. It shows that the proportion of student scores who have achieved a score of 70 is more than $70 \%$. Based on the effectiveness criteria, problem-based learning is declared effective in learning achievement.

Then the problem-solving skills test results also determine the criteria for the effectiveness of the implementation of problem-based learning. The descriptive analysis of problem-solving skills results is summarized in Table 3.

Table 3. Problem solving ability test results

\begin{tabular}{|l|l|}
\hline Description & Score \\
\hline The highest score & 90 \\
\hline Lowest Value & 45 \\
\hline Completed student & 22 \\
\hline Student not finished & 6 \\
\hline Completeness presentation & $78,5 \%$ \\
\hline
\end{tabular}

Based on the data that has been collected from the results of the study, then a $\mathrm{Z}$ proportion test is carried out. Problem-based learning is declared effective in terms of problem-solving skills if the proportion of students who achieve a minimum good category is more than $70 \%$.

Based on the sample data, it is obtained the value of $\mathrm{Z}=1.782$, and because $\mathrm{Z} 0.05=1.645, \mathrm{Z}>\mathrm{Za}$. It can be concluded that the proportion of student scores who have achieved a problem-solving skill score in the 
minimum good category is more than $70 \%$. Based on the effectiveness criteria, problem-based learning is declared effective in problem-solving skills.

The following hypothesis test tests the effectiveness of problem-based learning in student self-confidence. The descriptive analysis of students' self-confidence results are summarized in Table 4.

Table 4. Results of the confidence questionnaire

\begin{tabular}{|l|l|l|}
\hline Category & \multicolumn{2}{|l|}{ Score } \\
\hline Very good & Before & After \\
\hline Well & 0 & 5 \\
\hline Enought & 10 & 20 \\
\hline Not enought & 14 & 3 \\
\hline Veryless & 4 & 0 \\
\hline
\end{tabular}

Based on the data obtained, a test was first conducted to determine whether the average score of the questionnaire after learning was more than the average score of the questionnaire before learning.

This test was conducted using the Paired Samples Test. The decision criterion is that $H 0$ is rejected if the significance is less than 0.05 . From the test results, obtained a significance $=0.012$. It means that the average self-confidence score after the implementation of problem-based learning is more than the average selfconfidence score before the application of problembased learning. Problem-based learning is declared effective if the proportion of students who have achieved a confidence score in the minimum good category is more than $75 \%$. From the sample data, the calculation results are $Z=2.898$, and because $Z=1.645$ means that $\mathrm{Z}>\mathrm{Za}$. The proportion of students who get a confidence score in the minimum good category is more than $75 \%$. Based on the existing effectiveness criteria, problem-based learning is effective in student selfconfidence.

\subsection{Discussion}

Today's mathematics learning is in dire need of innovation. One of the innovations in learning that can be chosen is applying a learning model that supports the development of thinking skills to support independent learning. However, in reality, an existing learning model does not necessarily guarantee that it effectively applies to every material or concept in mathematics. Therefore, it is necessary to prove in the form of experiments. This study applied a problem-based learning model to the statistics course.

Based on the results of the research results described previously, the results obtained that learning using a problem-based learning model is effective in terms of each aspect studied, namely learning achievement, problem-solving skills, and self-confidence. Problembased learning is a series of stages of the learning process that uses non-routine problems as a focus to develop problem-solving skills, mastery of the material, and self-regulation [14]. The steps in problem-based learning are as follows: a) finding the problem; b) building a work structure; c) defining the problem; d) collecting various information; e) formulating solutions; and f) evaluation [11], [14-18].

The first step is to find the problem. At this stage, students are facilitated to understand the issues presented. The problems presented are non-routine problems related to statistical concepts. Thus, students can realize that the problem is essential and requires time and attention to be solved. The second and third steps are to build a work structure and define the problem. In this step, students build a work structure by expressing what they know about the existing situation and what ideas can solve it.. The problem is then packaged in the form of a problem formulation. The fourth step is collecting and sharing information. This step encourages students to collect and share the necessary information with their group mates to solve problems. The last step is to formulate a solution and evaluate. Students in groups develop solutions for solving the issues they face. Formulating solutions is done collaboratively and cooperatively by emphasizing aspects of effective communication in groups. At this stage, students look enthusiastic in the problem-solving process. Each step in problem-based learning is beneficial in developing problem-solving skills and indirectly supports the development of student confidence as prospective teachers.

In terms of learning achievement, it can be stated that problem-based learning is effective. Problem-based learning steps can facilitate students in understanding the material. In the problem-solving step, the information that students have obtained during learning activities can be applied by students to analyze and review the problems. Achievement refers to an individual's obtaining information, especially concerning academic progress [25]. In addition, the student worksheets have provided activities for students to understand the material and process information. It certainly has a positive impact on student achievement.

At the end of the lesson, students are allowed to express their experiences, difficulties or obstacles, while working on problems. This opportunity facilitates students to continue improving the product to be even better. In addition, the teacher reflects on the learning done by asking several questions such as whether problem-based learning is fun, what makes them interested in this learning, what is impressive during the problem-solving process, and so on. This activity can also have a positive impact on student self-confidence. Problem-based learning used in this study begins with finding problems, analyzing problems, building work structures, defining problems, collecting various information, formulating solutions, and evaluating. Based on the explanation from the previous paragraph that in problem-based learning, students can develop initiative in work, motivate internally to learn, and develop interpersonal relationships in group work. 
The effectiveness of problem-based learning is measured by learning achievement, problem-solving skills, and student self-confidence. Problem-based learning encourages students to be actively involved in constructing their knowledge so that student-centered learning activities become more meaningful. Problembased learning teaches students not only content but also skills [26]. Thus students can build and construct their knowledge and retain more information when they learn by doing [27]. In terms of problem-solving skills, problem-based learning is also effective. Problem-based learning steps can train students' problem-solving skills. In the design step of solving problem steps, students try to design the process that will be taken in finding solutions and try to solve a problem and challenge, which is then directed to make their own decisions. In this activity, students are trained to use problem-solving skills. In addition, in problem-based MFIs, problemsolving exercises encourage students to find solutions to the problems given.

In terms of self-confidence, problem-based learning has also proven to be effective. Problem-based learning encourages the student to discuss to find solutions to the problems encountered. This activity can train students to increase their self-confidence because students practice looking calm and have no fear when dealing with crowds and train students to be responsible for their tasks. Students are trained to believe in their abilities in conveying their ideas during discussions and develop them into a solution formulation so that students can be optimistic about the solutions they produce. Someone who believes that he can solve problems, achieve goals, or perform tasks competently shows that he has selfconfidence [28]. In addition, confidence in self-ability, optimism, and responsibility support students in increasing self-confidence. Lauster also said the same ideas [12], that belief in self-ability, optimism, and responsibility are aspects of self-confidence. The results of this study support previous research that states that problem-based learning is effective in learning achievement, problem-solving skills, and student selfconfidence [29]. Then the results of other studies also show that problem-based learning is effective for improving higher-order thinking skills and is also effective in terms of attitude, namely self-confidence. [17]. Thus problem-based learning is proven to improve student achievement, problem-solving skills, and student self-confidence.

\section{CONCLUSION}

The results show that the proportion of studentteacher candidates whose learning achievement reaches 70 is more than $70 \%$. In comparison, the proportion of student-teacher candidates with problem-solving abilities in the "good" category is more than 70\%. The proportion of student-teacher candidates who have selfconfidence in the "good" category is more than $75 \%$. Therefore, it can be concluded that problem-based learning is effective in learning achievement, problemsolving skills, and self-confidence.

\section{ACKNOWLEDGMENTS}

The article and the research behind it could have been completed with the tremendous support from Cenderawasih University, Yogyakarta State University, and the Education Fund Management Institute.

\section{REFERENCES}

[1] M. Hosnan and R. Sikumbang, Pendekatan saintifik dan kontekstual dalam pembelajaran abad 21. Jakarta: Ghalia Indonesia, 2014.

[2] R. Ismail and O. R. Imawan, Meningkatkan penguasaan TPACK guru di papua melalui pelatihan pembuatan video pembelajaran pada masa pandemi covid-19, J. Masy. Mandiri, vol. 5, no. 1, 2021, [Online]. Available: https://journal.ummat.ac.id/index.php/jmm/artic le/view/3862.

[3] O. R. Imawan and R. Ismail, Meningkatkan kompetensi guru matematika dalam mengembangkan media pembelajaran 4.0 melalui pelatihan aplikasi geogebra, J. Masy. Mandiri, vol. 4, no. 6, pp. 1231-1239, 2020, [Online].

Available: https://journal.ummat.ac.id/index.php/jmm/artic le/view/3102.

[4] Y. Linguistika, E. Listyani, and H. Retnawati, Peta penguasaan materi matematika guru sma dan hubungannya dengan prestasi belajar siswa, in Proceedings Seminar Nasional Matematika dan Pendidikan Matematika, 2013, p. P-87.

[5] D. Boyd and H. Bee, Lifespan development (5th ed). Boston: Pearson Education, 2009.

[6] A. Nitko and S. Brookhart, Educational assessment of student (6th ed). Boston: Pearson Education, 2011.

[7] R. Ismail, Perbedaan keefektivan antara model pembelajaran kooperatif tipe numbered heads together dan tipe jigsaw ditinjau dari hasil belajar matematika, J. Pendidik. Dan Kewirausahaan, vol. 9, no. 1, pp. 42-58, 2021, doi: 10.47668/pkwu.v9i1.155.

[8] D. Ifenthaler, P. Isaias, J. M. Spector, D. G. Sampson, and Kinshuk, Multiple perspectives on problem solving in the digital age. New York: Springer Science Business Media, 2011.

[9] G. Polya, How to solve it: a new aspect of mathematical method. Princeton: Princeton University Press, 1988. 
[10] R. Ismail and F. Safitri, Peningkatan kemampuan analisa dan interpretasi data mahasiswa melalui pelatihan program SPSS, J. Masy. Mandiri, vol. 3, no. 2, pp. 148-155, 2019, [Online]. Available: https://journal.ummat.ac.id/index.php/jmm/artic le/view/1196.

[11] A. Tan, Creativity: A handbook for teachers. Singapore: World Scientific, 2007.

[12] M. Ghufron and R. Suminta, Teori-teori Psikologi. Yogyakarta: Ar-Ruzz Media, 2010.

[13] K. Burton and B. Paltts, Building confidence for dummies. Sussex: John Willey \& Sons, Ltd, 2006.

[14] D. Kauchak and P. Eggen, Strategi dan model pembelajaran: mengajarkan konten dan keterampilan berpikir. Jakarta: Indeks, 2012.

[15] R. Fogarty, Problem-based learning and other curriculum models for the multiple intelligences classroom. Thousand Oaks: Sage Publication Inc, 1997.

[16] M. Hosnan, Pendekatan saintifik dan kontekstual dalam pembelajaran abad 21 . Bogor: Ghalia Indonesia, 2014.

[17] R. Ismail, Perbandingan keefektifan pembelajaran berbasis proyek dan pembelajaran berbasis masalah ditinjau dari ketercapaian tujuan pembelajaran, Pythagoras, vol. 13, no. 2, 2018, [Online]. Available: https://journal.uny.ac.id/index.php/pythagoras/a rticle/view/23595.

[18] J. R. Mergendoller, N. Maxwell, and Y. Bellisimo, The effectiveness of problem- based instruction: a comparative study of instructional methods and student characteristics, vol. 1, no. 2, pp. 49-69, 2007.

[19] R. Ismail, H. Retnawati, and O. Imawan, Model pembelajaran project-based learning \& problembased learnin: untuk ketercapaian tujuan pembelajaran siswa SMP. Banyumas: Pena Persada, 2021.

[20] B. Karatas and A. Baki, The effect of learning environments based on problem solving on students' achievements of problem solving, Int. Electron. J. Elem. Educ., vol. 5, no. 3, pp. 249$268,2013$.

[21] W. Trochim and J. P. Donnelly, The Research Methods Knowledge Base - Read online. https://www.ebooksdirectory.com/details.php?ebook $=2917$ (accessed Dec. 04, 2021)

[22] R. L. Ebel and D. A. Frisbie, Essentials of Educational Measurement. Englewood Cliffs, NJ: Prentice Hall, 1991.

[23] R. Johnson and W. D. W, Applied multivariate statistical analysis (6th ed). New Jersey: Pearson Prentice Hal, 2007.

[24] P. Tandililing and R. Ismail, Pengantar Statistika Terapan. Banyumas: CV. Pena Persada, 2021.

[25] B. . Garber, Developmental psychology for family law professionals: Theory, application and the best interests of the child. New York: Springer Publishing Company., 2009.

[26] J. Stivers, Project based learning: A dynamic approach to teaching in which students explore real-world problems and challenges, simultaneously developing 21 st century skills while working in small collaborative groups, Educ. Psychol., 2010.

[27] S. Bell, Project-based learning for the 21st century: Skills for the future, Clear. House A J. Educ. Strateg. Issues Ideas, vol. 83, no. 2, pp. 39-43, 2010.

[28] D. H. Schunk, Learning Theories. New Jersey: Pearson education, 2012.

[29] O. R. Imawan, Perbandingan antara keefektifan model guided discovery learning dan projectbased learning pada matakuliah geometri, pythagoras, vol. 10, no. 2, pp. 179-188, 2015, [Online]. Available: https://journal.uny.ac.id/index.php/pythagoras/ar ticle/view/9156. 